Apresentação - Dossiê: Ethos Contemporâneo e Religião (c) (i)

\title{
Horizonte, v. 15, n. 46, abr./jun. 2017
}

Dossiê: Ethos Contemporâneo e Religião

Dossier: Contemporary Ethos and Religion

Antonio Geraldo Cantarela *

Editor

Os debates sobre o ethos contemporâneo atravessam as mais diversas áreas de conhecimento. A educação e seus desafios, a política, os processos midiáticos, as novas tecnologias, o consumo, a vida urbana, a violência, as artes... não há assunto de interesse social que não tenha sido tratado em correlação com "ethos contemporâneo". Também no âmbito das Ciências da Religião, o tema se faz presente para amparar debates sobre a radical pluralidade religiosa que marca nosso tempo, o franco abandono das igrejas tradicionais, a adoção de formas de espiritualidade menos afeitas aos modelos daquelas instituições e, no extremo, a escolha do ateísmo como proposta de sentido. Horizonte dedica este número ao assunto. Agradecemos a especial colaboração dos professores Flávio Augusto Senra, Fabiano Victor Campos e Henrique Lott na organização do dossiê.

No Editorial, Manfredo de Oliveira fala de ética como normatividade sobre o dever-ser humano. Destaca, em relação ao contexto pluralista contemporâneo, a tendência a negar a possibilidade de legitimar normas e princípios universais. Frente a isso, o autor propõe algumas questões acerca da relação entre o universal dos critérios referenciais e a particularidade das situações históricas.

\footnotetext{
${ }^{*}$ Doutor e Mestre em Letras/Literatura. Professor adjunto da PUC Minas do PPGCR. País de origem: Brasil. E-mail: agcantarela@yahoo.com.br.
} 
O Dossiê traz oito artigos com abordagens diversas sobre as relações entre a religião e o ethos contemporâneo. O primeiro artigo, intitulado Para ler Gauchet 20 anos depois, assinado por Carlos Alberto Steil, propõe-se a pensar criticamente as teses de Gauchet, 20 anos depois de Le Désenchantement du Monde, publicado em 1985. Dentre os aspectos discutidos por Steil, está o lugar subordinado que a religião ocupa no pensamento de Gauchet. Steil propõe “a urgência em se superar a dicotomia entre o secular e o religioso".

O segundo artigo, de Fabiano Victor Campos, analisa o sentido da expressão "desencantamento do mundo" no pensamento de Marcel Gauchet. Percorre o pensamento do filósofo francês em seu desenvolvimento histórico-analítico e discute, a partir dele, as condições de possibilidade da religião e da espiritualidade nos tempos atuais.

$\mathrm{O}$ artigo de Henrique Marques Lott, intitulado Marcel Gauchet e a saída contemporânea da religião, aborda a situação atual da saída da religião no âmbito da teoria de Marcel Gauchet, dirigindo o foco para alguns conceitos fundamentais da obra daquele filósofo. Lott destaca que a experiência de desencantamento do mundo não elimina a religião nem a fé religiosa.

$\mathrm{O}$ artigo de Philippe Portier, intitulado La question lä̈que dans la France d'aujourd'hui: réflexions sur un passage de la norme à la valeur, fala do percurso da laicidade no decorrer dos anos 80 aos dias de hoje, a partir da experiência europeia, mais particularmente da França. O texto assinala "como se dão as renovações e ressignificações teóricas que o termo laicidade adquire com o avanço do reconhecimento de novas reivindicações religiosas no quadro contemporâneo”.

O quinto artigo do Dossiê, da autoria de Carlos Mauro Oliveira Júnior, fala de Dúvidas, liberdade e religiosidade, a partir das ideias de sentimento religioso formuladas por Benjamin Constant, nos inícios do século XIX. Para o político e escritor francês, a religião, desde que separada das facções sacerdotais, é necessária para sociedades livres. 
$\mathrm{O}$ artigo de Daniel Toledo - A precariedade existencial como condição essencial de compreensão para a experiência religiosa na contemporaneidade fala sobre a referência ontológica que subjaz a toda experiência religiosa. O autor procura evidenciar "em que medida a nossa condição existencial de finitude é impositiva para se compreender as mais variadas formas de manifestações dos fenômenos religiosos que afloram na contemporaneidade".

Na esteira das exigências para a evangelização, formuladas pelo Vaticano II, Joana Terezinha Puntel discute $A$ transmissão da fé na nova arquitetura da comunicação contemporânea. A autora destaca que no processo comunicativo da cultura digital, a comunicação unidirecional cede lugar aos processos interativos e colaborativos. "Na era digital novas linguagens desafiam paradigmas tradicionais e nos impelem para uma mudança de mentalidade e de prática pastoral.”

O último artigo do Dossiê, de autoria de Leno Francisco Danner, Agemir Bavaresco e Fernando Danner, aborda As diferenças como ethos e práxis contemporâneos. Tomando como referência as religiões institucionalizadas, os autores falam sobre a dialética entre fundamentação e aplicação de paradigmas normativo-religiosos.

Na seção de Temática Livre, o artigo assinado por Denise Rocha coloca em cena um conflito de fé e dogma, entre um huguenote e um católico, acerca da (in)dissolubilidade do matrimônio. O pano de fundo da questão é a Luanda do século XVII, então ocupada pelos holandeses, encenada no romance $A$ gloriosa família (de 1997), do escritor angolano Pepetela.

O artigo de Veronique Lecaros - Dios castigador, Dios Juez o Dios amado? - destaca, a partir de pesquisa em meios católicos e pentecostais, alguns traços da concepção de Deus na piedade popular peruana. A autora mostra que percepções antagônicas de Deus - juiz divino e todo-poderoso ou protetor e provedor harmonizam-se e se completam na imagem de um Deus garantidor da ordem justa do mundo. 
O artigo de Pierre Normando Gomes-da-Silva configura um ensaio a partir de revisão teórico-bibliográfica e de levantamento histórico sobre o trato educacional construído por ocasião da Reforma Protestante. Tal projeto pensava "uma escola para todos, laica, capaz de assumir a integralidade do homem em sua espiritualidade e corporeidade".

Emiliano Acosta oferece uma concepção de diálogo inter-religioso a partir do legado imaginário e conceitual da Ilustração. O texto traz, ao final, algumas reflexões com vistas a delinear uma prática de diálogo inter-religioso.

A seção de Comunicações traz um texto de Carlos Eduardo Souza Aguiar, que aponta Os paradoxos da presença da Igreja Católica nas redes. O autor destaca o contraste entre, de um lado, a estrutura e o modelo de comunicação tradicionais da Igreja Católica e, de outro, as exigências de colaboração e interação trazidas pela era digital.

Este número de Horizonte divulga o resumo da Dissertação de Mestrado de Thaís Silva de Assis. Trata-se de um estudo sociológico sobre um grupo de vedanta ou, conforme o título, o "neo-hinduísmo carioca".

Horizonte oferece, ainda, quatro resenhas sobre diferentes temas de interesse às ciências da religião: comunicação, temporalidade, teologia pública e gênero.

A todos, boa leitura. 